\title{
Crafting Trust
}

\section{The Role of Political Institutions in a Comparative Perspective}

\author{
Markus Freitag \\ University of Konstanz, Germany \\ Marc Bühlmann \\ Centre for Democracy, Aarau, Switzerland
}

\begin{abstract}
In this article, the authors evaluate the origins of generalized trust. In addition to examining individual-level determinants, the analytic focus is on the political-institutional context. In contrast to most of the analyses to date, the authors conduct hierarchical analyses of the World Values Surveys (19951997 and 1999-2001) to simultaneously test for differences among respondents in 58 countries and for variations in levels of trust between countries with different institutional configurations. In addition, the authors extend the institutional theory of trust by introducing the power-sharing quality of institutions - a rather neglected institutional dimension hitherto. With regard to the most important contextual factors, the authors find that countries whose authorities are seen as incorruptible, whose institutions of the welfare state reduce income disparities, and whose political interests are represented in a manner proportional to their weight have citizens who are more likely to place trust in one another.
\end{abstract}

Keywords: social capital; trust; institutions; comparative politics; multilevel analysis

$\mathrm{T}$

Trust is the "core of social capital" and one of the key resources for the development of modern societies. ${ }^{1}$ A high level of social trust promotes an inclusive and open society, increases the likelihood of investment in the future, promotes economic development, and fosters societal happiness and a general feeling of well-being (Fukuyama, 1995; Gabriel, Kunz, Rossdeutscher, \& Deth, 2002; Herreros, 2004; Herreros \& Criado, 2008; Newton, 2001; Stadelmann-Steffen \& Freitag, 2007; Uslaner, 2002; Whiteley, 2000). This concept is of particular interest because it is prominent in not only the debates of social scientists but in everyday discourses as well (see Offe, 1999). In everyday life, we appreciate the 
importance of trust whenever we encounter the risks of modern society. Parents, friends, and even the popular media warn us not to blindly place our trust in strangers, politicians, or even our investment advisors. On the other hand, we have to recognize that a certain amount of trust is a prerequisite for the most basic cooperation in our economic, political, and social relationships. Increasing mobility, a greater division of the labor force, and new communications technologies force us to cooperate with and place our trust in those whom we do not know personally. The impact trust has on social, political, and economic variables has been extensively researched by social scientists; however, relatively little attention has been paid to the conditions under which trust can develop. How is social trust crafted? Which individual- and societal-level characteristics, attitudes, and circumstances promote the development of trust? How can we trust those whom we do not know personally? These are the questions that guide our contribution.

Although a growing number of studies ask who trusts and why, three important issues remain to be addressed. First, in addition to the contribution to the extant literature, this article will also present a methodological innovation in research on trust. The majority of previous studies attempt to explain aspects of trust separately, both at the individual and/or societal levels (Delhey \& Newton, 2005; Freitag, 2003a, 2003b, 2006; Gabriel et al., 2002; Newton \& Norris, 2000; Rothstein \& Stolle, 2003; Uslaner, 2002). However, the effect of contextual factors on individual-level trust is relatively neglected. Our approach is to use hierarchical models to simultaneously illuminate individual, societal, and in particular, politicalinstitutional conditions for the creation of trust in a systematic comparative manner. In empirical social research, this methodology is seen as a tried and tested means for overcoming micro-macro dualism because individual attitudes and behavior are structured both by personal traits and the social context (Anderson \& Singer, 2008; Herreros \& Criado, 2008; Paxton, 2007). In other words, societal conditions structure individual attitudes and influence personal behavior.

Authors' Note: This article was written as part of a research project by the authors on worlds of social capital that was carried out within the framework of the Excellence Initiative of the German Research Foundation (in particular the Cluster of Excellence "Cultural Foundations of Social Integration" and the Research Centre "Volunteering and Social Capital"). An earlier version of this article was presented at the ECPR Joint Sessions 2007, Helsinki, Workshop No. 1, Social Capital, the State and Diversity. We are grateful to the participants in the workshop and the three anonymous referees for their helpful comments and suggestions. 
Second, whereas many previous studies suggest that trust is produced primarily by social factors such as participation in civic groups and associations (see among others, Paxton, 2007; Putnam, 2000), we argue that an important source of generalized trust is to be found in political institutions. In this vein, we place political institutions at the center of our analysis of trust formation. Our hypothesis then follows that political institutions contribute to the development of trust when individuals perceive them to be universalistic, power-sharing, incorruptible, nonpartisan, and sanctioners of noncooperative behavior. When people come to believe that political institutions exhibit these qualities and perceive to share these sentiments with their fellow citizens, they will generally trust others in that society-even if they do not know them personally. We argue that generalized attitudes toward others and political institutions are inherently intertwined (Crepaz, 2008; Rothstein, 2005; Rothstein \& Stolle, 2003, pp. 199-200; You, 2005). Although institutions can stimulate or prohibit individual-level attitudes and trustworthy behavior through different incentives and qualities, human behavior is not only influenced by material incentives of institutions. Furthermore, institutions shape values, norms, perceptions, and habits through socialization mechanisms and make people inherently trustworthy and trusting.

Third, although some strands of social capital theory suggest that one of the most important possible explanations of trust is the politicalinstitutional context (Freitag, 2006; Nannestad, 2008; Neller, 2008; Rothstein \& Stolle, 2003; You, 2005) in which individual trust is embedded, previous studies do not acknowledge the power-sharing characteristics of political institutions in depth. Whereas many studies highlight the institutionally guaranteed rules of law or the universality of institutions for their explanation of the development of trust (Rothstein \& Stolle, 2003; You, 2005), the power-sharing aspects of institutions have received much less attention. We therefore wish to expand the existing institutional theory by adding a further innovative mechanism of trust building. In doing so, we argue that institutions, which follow a consensus logic, promote generalized trust-especially those characterized by power-sharing, the integration of minorities, and the reduction of cultural, social, and political distances ${ }^{2}$.

The data for our analysis come from the World Values Survey (19992001) of 58 countries (Inglehart, Basanez, Diez-Medrano, Halman, \& Luijkx, 2004) and from official statistics for the aggregate-level data. ${ }^{3}$ The selection of cases is based less on the content of our theory but rather on the availability of both individual- and societal-level databases. The analysis of the causes of trust creation follows four steps: The next section of this article introduces the dependent variable. The theory linking institutional conditions 
to the creation of social trust is presented in the following section. The next section elaborates on the methodology used and then subjects the various independent variables to systematic empirical testing in a number of hierarchical models; finally, the most important findings are summarized.

\section{Social Trust-The Dependent Variable}

The interest in social trust in recent years is primarily vested in the introduction of the concept of social capital in the social sciences during the 1990s. Within this literature, trust plays the key role of generating cooperation (Herreros, 2004; Herreros \& Criado, 2008; Putnam, 2000; Uslaner, 2002). Generally speaking, trust can be described as the conviction that the actions of another party (an individual or a group) can be depended on (Offe, 1999). With regard to the scope of the phenomenon, one can generally identify two distinct kinds of trust, namely, particularistic and generalized trust. Particularistic trust is based on a personal association with the trustee and as such can be extended to easily comprehended groups (family, friends, neighbors, colleagues). In other words, such trust relationships are based on shared experiences and the expectation of future interaction between the parties. The foundation of this form of trust is the sum of the common experiences that we consciously bring to the relationship. So conceived, trust is a cognitive phenomenon with a narrow application. Strangers are only accepted into the ranks of the trusted insofar as they satisfy predetermined criteria for group membership such as age, gender, ethnicity, or religious affiliation.

Our primary focus in this article, generalized trust, is not confined to narrow worlds of life experience. Generalized trust differs from particularistic trust in that it deals with unknown groups and/or strangers and does not predominantly hinge upon specific situations (Stolle, 2002). Moreover, this form of trust does not presuppose calculations of the probability that the prospective trustee can in fact be trusted; rather, it allows for actions to be motivated by altruism, concern for the common good, and the expectation that unilateral advances of trust will be reciprocated at an unspecified time and from an unspecified person (Whiteley, 2000). This environment of general reciprocity furthers a certain "ontological security" for individuals (Sztompka, 1995, p. 257), makes cooperation possible, and minimizes the risks involved in the act of trust.

Measures of generalized trust can be typically found in surveys that pose the following type of question: "Generally speaking, would you say that most people can be trusted or that you can't be too careful in dealing with people?" (Uslaner, 2002, p. 54). Table 1 presents an overview of levels of 
Table 1

Generalized Trust in 58 Countries, at the End of the 1990s

\begin{tabular}{|c|c|}
\hline Country & Generalized Trust \\
\hline Denmark & 66.5 \\
\hline Sweden & 66.3 \\
\hline Norway & 65.3 \\
\hline Netherlands & 59.8 \\
\hline Finland & 58.0 \\
\hline New Zealand & 49.1 \\
\hline Japan & 43.1 \\
\hline India & 41.0 \\
\hline Switzerland & 41.0 \\
\hline Australia & 39.9 \\
\hline Canada & 38.8 \\
\hline Spain & 36.2 \\
\hline United States & 35.8 \\
\hline Ireland & 35.2 \\
\hline Germany & 34.8 \\
\hline Austria & 33.9 \\
\hline Italy & 32.6 \\
\hline Belgium & 30.7 \\
\hline Ukraine & 27.2 \\
\hline Bulgaria & 26.9 \\
\hline Dominican Republic & 26.4 \\
\hline Luxembourg & 26.0 \\
\hline Lițuania & 24.9 \\
\hline Armenia & 24.7 \\
\hline Albania & 24.4 \\
\hline Czech Republic & 23.9 \\
\hline Greece & 23.7 \\
\hline Russia & 23.7 \\
\hline Bangladesh & 23.5 \\
\hline Estonia & 22.8 \\
\hline Chile & 22.8 \\
\hline France & 22.2 \\
\hline Uruguay & 22.1 \\
\hline Hungary & 21.8 \\
\hline Slovenia & 21.7 \\
\hline Mexico & 21.3 \\
\hline Azerbaijan & 20.5 \\
\hline Poland & 18.9 \\
\hline Serbia & 18.8 \\
\hline Georgia & 18.7 \\
\hline Croatia & 18.4 \\
\hline
\end{tabular}


Table 1 (continued)

\begin{tabular}{lc}
\hline Country & Generalized Trust \\
\hline Latvia & 17.1 \\
Bosnia/Herzegovina & 15.8 \\
Turkey & 15.7 \\
Slovakia & 15.7 \\
Argentina & 15.4 \\
Moldova & 14.7 \\
Macedonia & 13.5 \\
Zimbabwe & 11.9 \\
South Africa & 11.8 \\
Colombia & 10.8 \\
Peru & 10.7 \\
Romania & 10.1 \\
Portugal & 10.0 \\
Philippines & 8.4 \\
Tanzania & 8.1 \\
Uganda & 7.6 \\
Brazil & 2.8 \\
\hline
\end{tabular}

Note: Data were used from 58 countries covered in the World Values Surveys (WVS) from 1995-1997 and 1999-2001. The following countries were excluded due to missing data on key variables: Algeria, El Salvador, Indonesia, Israel, Jordan, Malta, Morocco, Nigeria, Pakistan, Egypt, Great Britain, Venezuela, Iceland, Taiwan, Belarus, Montenegro, and Northern Ireland. Generalized trust is measured using responses to the question: "Generally speaking, would you say that most people can be trusted (1) or that you can't be too careful in dealing with people (0)?" Calculations are made using the WVS weightings (Inglehart, Basanez, DiezMedrano, Halman, \& Luijkx, 2004).

generalized trust for 58 countries based on responses from the World Values Surveys for the years 1995 to 2001. These figures indicate that the level of generalized trust ranges from a high in Scandinavia, where the majority of people are willing to trust others, to lows in some African states (Tanzania, Uganda), some South American states (Brazil, Peru, Colombia), and the Philippines and Romania. They also undermine the notion that the level of trust in individual countries could be linked one-to-one to a specific type of culture. The Western European countries fall mainly together but are interspersed with other countries such as Australia, New Zealand, Japan, and India. One can find countries from Eastern Europe, Asia, and Latin America in both the second and the third thirds of the distribution. If we are unable to find explanations based on shared historical-cultural experiences and their expression in modern convictions and attitudes, then how are we to 
explain the varying levels of trust? Providing an answer to this question is the task of the next section.

\section{Theories and Hypotheses of Crafting Trust Through Institutions}

The previous introduction to the concept of trust leads us to a central problem: If social trust is created in interactions between people and groups, how are we to trust those whom we do not know? In other words, the central objective of analysis remains in examining the question of how to broaden the scope of trust beyond the narrow domain of primordial social units (Eisenstadt, 1995). This question is of particular importance in the modern context of high mobility and the need to be able to cooperate with those with whom we have no prior acquaintance or shared experience. In this vein, we expect strangers to have no reason to either place trust in or be trusted by others (Offe, 1999).

At the core of the present analysis is the perspective that institutional rules and conflict resolution mechanisms act as catalysts for generalized trust. This view is supported by the key insights of rational choice theorynamely, that binding regulations make cooperation possible and encourage the generation of trust between the interactive parties (Levi, 1998; Nooteboom, 2007; Offe, 1999). Furthermore, our approach also follows in the tradition of "new institutionalism" in political science (see Hall \& Taylor, 1996). In contrast to the earlier historical-descriptive institutionalism, which focused on rules and constitutions, the new institutionalism takes an explicitly empirical approach to the analysis of the effectiveness and regulative power of political institutions. Institutions can structure the exchange of information or various types of behavior and can also impose sanctions. In this sense, institutions can stimulate individual attitudes and trustworthy behavior through different incentives (Offe, 1999). If citizens feel that they are not treated fairly by the authorities and politicians, their self-esteem will be negatively influenced, thereby shaping how they behave toward strangers or unknown people. If the officials of the government or the public administration are not fair and trustworthy, why should the rest of society be (Rothstein \& Stolle, 2003)? On the other hand, institutional arrangements produce particular habits and norms of trustworthiness, such as intolerance of corruption, cheating, or the exploitation by majorities as unacceptable behavior, thus making people inherently trustworthy through 
socialization mechanisms. As trust and trustworthiness mutually reinforce one another (Putnam, 2000), political institutions will affect the way people trust other people. ${ }^{4}$

The central assumption of our approach is that trust-based relationships do not have to be based on long-term acquaintances or repeated exchange between specific people and groups. The implication is that generalized trust can develop when institutions offer incentives that encourage people to act in collaboration; I will trust others given conditions promoting corresponding collaborative dispositions among all. Under the context of such institutions, I trust others not because I know them personally but because I know about the constraints that these institutions place upon their actions. Institutions with these trust-generating functions can make quasi-acquaintances out of strangers. The question is then, which substantive qualities must these institutions have to act as catalysts for trust between strangers? ${ }^{5}$

First, institutions must enshrine concepts such as fairness, justice, incorruptibility, nonpartisanship, truthfulness, or even transparency as the core norms of communal living (Delhey \& Newton, 2005; Levi, 1998; Neller, 2008; Offe, 1999). These institutions generalize trust to the extent that they transparently hold the members of society to these norms and impose sanctions on those who breach them. Influenced by fairness-generating institutions and with the knowledge that sanctions will be imposed on those who violate these norms, each person comes to trust others. These institutions create a reliable environment in which personal security is assured and social trust is not abused. As long as the institutions themselves are seen as incorruptible, nonpartisan, and just, as well as able to impose sanctions on degenerate behavior, they are able to support the actions of honest people and help to encourage trust in others: "Trust is underwritten by a strong government to enforce contracts and to punish theft. Without such a government, cooperation would be nearly impossible and trust would be irrational" (Hardin, 1992, p. 161). If there is reason to suspect that the rule of law in a given country is weak, such that legal organs like the judicial system or law enforcement are unable to ensure secure contracting or prevent some actors from receiving privileges, mistrust between individuals is more likely to develop. This discussion leads to the following working hypothesis:

Hypothesis 1: Institutions that are seen as incorruptible, nonpartisan, just, and sanctioners of uncooperative behavior have a greater capacity to promote social trust. Increased individual trust in the judicial and law enforcement systems, a stronger rule of law, a more independent judiciary, and lower levels 
of corruption increase the likelihood that an individual will develop a high level of generalized trust.

The second key attribute of institutions is the extent to which they are universally oriented and provide their citizens with equal opportunities to develop trust (see Boix \& Posner, 1998; Kääriäinen \& Lehtonen, 2006; Kumlin \& Rothstein, 2005; Neller, 2008; Oorschot \& Arts, 2005; Rothstein \& Stolle, 2003; Rothstein \& Uslaner, 2005). Compared to social insurance systems that entrench class stratification, or means-tested poverty relief systems, a universalistic welfare state has the following advantages: One can assume that people who receive assistance on the basis of equal rights and responsibilities are less likely to be stigmatized as "others." Moreover, universalistic programs have been shown to be less likely than means-tested programs to generate the impression that the system is being exploited (Rothstein \& Stolle, 2003). Universalistic welfare states reduce fears that one is either being exploited by other members of society or robbed of the equal opportunity to lead a successful life. ${ }^{6}$ They do so by reducing inequality and providing certain key resources. Empirical analyses in turn have established that generalized trust can be explained, among other things, by the level of inequality in society (Rothstein \& Uslaner, 2005). Universal programs for education and health care may particularly increase the feeling of "equal opportunity" among large segments of the population, which should then further social trust (Rothstein \& Uslaner, 2005). For example, the Scandinavian countries, with their prototypical universalistic welfare states, exhibit the highest levels of social trust and relatively high income equality as well as greater equality between the sexes (Kumlin \& Rothstein, 2005; Rothstein \& Stolle, 2003). These findings lead us to the next working hypothesis:

Hypothesis 2: More universally oriented systems are more likely to promote the development of generalized trust. Greater income equality and increased activity by the state in promoting equal opportunities promote the probability that individuals will develop generalized trust.

The final relevant quality of institutions is the extent to which mechanisms of conflict resolution (that are consensual and provide protection to minorities) are present (Levi, 1998). We can conceive of two mechanisms through which inclusive, minority-protecting institutions can promote generalized trust. The first link between these qualities of institutions and generalized trust deals with cognitive inferences. That is, citizens make inferences based on their experiences with a system and extend them to 
everyone else within the same political system (Rothstein \& Stolle, 2003). In this vein, if Person A notices that biased institutional decisions systematically tend to privilege Person B, Person A is likely to lose trust in the political institutions that disadvantage Person A, relative to Person B. The ways in which political institutions are configured shape the public's perception of them. If they appear to be partisan, systematically exclude certain interests, and promote a "winner-takes-all" mentality, they will generate mistrust among the people whom they place at a disadvantage. Against this background, there is need for a crucial distinction between different types of democracies. Democracy is about winning and losing within the context of set rules to which those participating in political contests must adhere. Nevertheless, it is important to note that some institutions are designed to afford greater opportunities of representation in the political arena to both winners and losers of democratic competition. Because a more consensual set of political institutions provide minorities (or potential losers of the democratic struggle) with a voice in the decision-making process, some of the negative consequences of losing elections are dampened by the system. Conversely, the more majoritarian the institutions, the louder the winners' voice, and therefore their ability to impose their will on the minority will also be greater (Anderson \& Guillory, 1997). Under this configuration, how can citizens with these experiences (the losers) trust people at all if they perceive the majority's interest to be contrary to theirs? These tendencies are magnified when institutional structures deny minorities the chance to participate and do not prohibit their systematic exploitation by majorities (Gabriel et al., 2002). If citizens experience systematic discrimination, as many minority groups in democracies do, and if people are singled out as special cases due to the given decision-making process and/or perceive their voices as unheard, it seems plausible that the majority of people (the winners) do not trust them. With this in mind, it also appears plausible that those political-institutional configurations, which allow the manifold societal interests to proportionally partake in the decision-making process and therefore are also able to systematically integrate minorities into this process, are exactly those that are capable of fostering generalized trust. All in all, we believe that institutions that reduce the political and social distance between winners and losers provide a breeding ground for social trust.

The logic supporting the second mechanism of the generation of generalized trust refers to the capacity of institutions to shape behavioral dispositions and promote trustworthiness through transmitted values, norms, and ideas. This habit-formative function of an institution is realized when people living within these institutions are both cognitively familiarized and effectively 
imbued with normative ideas by the institutions through socialization mechanisms (Offe, 1999). In this regard, organizational structures that promote consensual decision making are seen to promote trust between actors due to the ways in which they involve participants and emphasize ideas such as amicability. ${ }^{7}$ More competitive organizational structures on the other hand are perceived to promote conflict and competition and as less inclusive-all of which can hinder the development of trust. Consensus democracies can thus be expected to heed the concerns of minorities, represent heterogeneous interests, and produce not only overall kinder and gentler societies (Lijphart, 1999) but also more trusting ones. In addition, the aspect of iterative bargaining as a core element of consensus democracy supplies the society with the norm of reciprocity. In this vein, consensual institutions, such as Coleman's (1990) examples of the Cairo marketplace and Southeast Asian rotating credit associations, provide the context for infinitely repeated games. This institutionalized shadow of the future determines the exchange of social obligations that should promote social trust among the members of a society. This third quality of institutions leads us to the following working hypothesis:

Hypothesis 3: Institutions with a greater capacity for consensual and powersharing are more likely to facilitate the development of social trust. The more transparent power-sharing structures are, the better the chances for minority participation through proportional representation, and the better political rights are protected, the more likely it is that individuals will develop generalized trust.

\section{Research Design, Method, Variables, and Data}

For the remainder of this article, our primary focus will be on testing the hypotheses presented previously. The dependent variable is the individual disposition to generalized trust. The objects of the analysis are 67,617 individuals in 58 countries. These data are obtained from the World Values Surveys from 1995-1997 and 1999-2001 (see Inglehart et al., 2000, 2004). ${ }^{8}$ In addition to contextual factors, we also include individual-level attitudes and characteristics in our hierarchical modeling of variations in the propensity to trust (see Jones, 1997). This modeling method simultaneously and statistically accurately estimates both the influence of contextual- and individual-level factors. It is only by modeling hierarchical structures in the data (every measure of an individual-level characteristic can be attributed to 
one of the countries in the sample) that we can encompass the influence of both individual-level and contextual factors (see Steenbergen \& Jones, 2002). The key to this approach is to model variance at the macro level, such that:

$$
y_{i j}=\beta_{0 j}+\beta_{1} X_{1 i j}+\varepsilon_{i j}
$$

where

$$
\beta_{0 j}=\beta_{0}+\mu_{0 j}
$$

$\left(\mu_{0 j}\right.$ are the residuals at the societal level).

Such a model implies that individual behavior can vary between countries. In other words, we do not assume that basic trust (the constant $\beta_{0}$ ) and the influence of the independent variables $\beta_{1}$ are the same in all countries but rather that we are dealing with variables that can vary according to context. Hierarchical models also allow for the modeling of specific macro features (e.g., particular political institutions) that explain variation on the macro level (e.g., from country to country). Furthermore, cross-level interactions-the influence of societal structures on the ways in which individual-level factors matter - can be controlled for. Schematically, such a two-level model takes the following form:

$$
\begin{gathered}
y_{i j}=\beta_{0}+\beta_{1} X_{1 i j}+\ldots+\beta_{k j} X_{k i j}+\ldots+\beta_{n} X_{n i j}+\alpha_{1} W_{1 j}+\ldots+ \\
\alpha_{n} W_{n j}+\gamma_{1} W_{k j} X_{k i j}+\mu_{1 j} X_{k i j}+\mu_{0 j}+\varepsilon_{i j}
\end{gathered}
$$

The generalized trust $(y)$ of an individual $(i)$ in a country $(j)$ is explained by the global average $\left(\beta_{0}\right)$, individual-level characteristics $(X$, or the coefficient $\beta)$, and features of the various countries ( $\mathrm{W}$, or the coefficient $\alpha$ ). In this manner, individual differences $\left(\varepsilon_{i j}\right)$, context-dependent differences in the underlying level of trust $\left(\mu_{0 j}\right)$, and differences in the effects of the independent variables $\left(\mu_{1 j} X_{k j}\right)$ are all covered in the model. Using the hierarchical model we estimate whether and to what extent the variance in individual generalized trust can be explained by differences between individuals, differences between countries, and differences in the effects of the independent variables. Variation between individuals and between contexts are explained by individual-level and contextual factors; variation of the effects of the independent variable $X_{k}$ are explained by crosslevel interaction effects between the $k$ th individual and the $k$ th contextual variable $\left(W_{k j} X_{k i j}\right.$, or the estimator $\left.\gamma\right)$. As such, the effect of the variable $X_{k}$ is randomized $\left(\beta_{k j}\right)$. As our dependent variable has a dichotomous form, we use logit, rather than ordinary least squares-based regression analysis. The methods of estimation and interpretation follow the convention for logit analyses. ${ }^{9}$

To capture the effects of institutional conditions, we include estimates of the quality of these conditions along the dimensions of fairness, universality, and 
Table 2

Qualities of Institutions and the Respective Indicators

\begin{tabular}{ll}
\hline Quality & \multicolumn{1}{c}{ Indicators } \\
\hline Fairness & Trust in the police (World Values Survey) \\
& Rule of law (Bertelsmann Foundation, 2003) \\
& Independent judiciary (Henisz, 2004) \\
& Degree of corruption (International Country Risk Guide, 2004; \\
& Kaufmann, Kraay, \& Zoido-Lobatón, 1999) \\
& Income inequality in the 1990s (CIA World Factbook, 2006) \\
Universality & Public health expenditures (World Health Organization, 2006) \\
& Power-sharing regime typology (Norris, 2005) \\
Power-sharing & Sharing of executive power (Keefer, 2002) \\
& System of proportional representation (Keefer, 2002) \\
& Degree of democracy (political rights; Freedom House, 2003) \\
\hline
\end{tabular}

Note: For a more complete discussion of operationalization and sources, see the appendix.

power-sharing (see Table 2). Whereas trust in the law enforcement (i.e., the police) is measured at the individual level, the other institutional variables are measured at the societal level. ${ }^{10}$ These include the rule of law, independence of the judiciary, estimated risk of corruption, degree of income inequality, state spending on health care, institutional and executive divisions of power, electoral system (the degree of proportionality), and scope of political rights. ${ }^{11}$

In addition to the institutional variables, empirical research on trust suggests a number of other potentially influential factors, both at the micro and macro levels (see Alesina \& La Ferrara, 2000; Delhey \& Newton, 2005; Freitag, 2003a, 2003b; Paxton, 2007; Putnam, 1993, 2007; Rothstein \& Stolle, 2003; Stolle, 2002; Stolle, Soroka, \& Johnston, 2008; Uslaner, 2002). Further details on the individual operationalizations can be found in the table in the appendix..$^{12}$

\section{Empirical Findings}

In this section we subject our theory-derived relationships to empirical tests, with a focus on the influence of institutional factors on the development of generalized trust. Following the logic of hierarchical modeling, we present a progression of models, each one building on the preceding one. To document the variation of the dependent variables at the individual and contextual levels, we begin by estimating an empty model (Table 3, Model 1). Building on the empty model, which excludes independent 
Table 3

Empty Model and Individual Models Explaining Generalized Trust

\begin{tabular}{|c|c|c|c|c|c|c|}
\hline & $\begin{array}{c}\text { Model } \\
1\end{array}$ & $S E$ & $\begin{array}{l}\text { Model } \\
2\end{array}$ & $S E$ & $\begin{array}{l}\text { Model } \\
3\end{array}$ & $S E$ \\
\hline \multicolumn{7}{|l|}{ Fixed effects } \\
\hline $\begin{array}{l}\text { Constant } \\
\text { Social networks }\end{array}$ & -1.16 & $0.11 * *$ & -2.11 & $0.12 * *$ & -2.27 & $0.12^{* *}$ \\
\hline $\begin{array}{l}\text { Activity in bridging } \\
\text { associations }\end{array}$ & - & & 0.18 & $0.02^{* *}$ & 0.17 & $0.02 * *$ \\
\hline $\begin{array}{l}\text { Activity in bonding } \\
\text { associations }\end{array}$ & - & & 0.17 & $0.03 * *$ & 0.16 & $0.03 * *$ \\
\hline $\begin{array}{l}\text { Marital status } \\
\text { Resources }\end{array}$ & - & & 0.00 & 0.02 & 0.00 & 0.02 \\
\hline & \multicolumn{5}{|c|}{ Attitudes and habits } & $0.03 * *$ \\
\hline Life satisfaction & - & & 0.77 & $0.05 * *$ & 0.73 & $0.05 * *$ \\
\hline Moral codes & - & & -0.02 & 0.06 & 0.01 & 0.06 \\
\hline Cosmopolitan orientation & - & & 0.10 & $0.04 * *$ & 0.14 & $0.04 * *$ \\
\hline $\begin{array}{l}\text { Religious } \\
\text { denomination }\end{array}$ & - & & -0.04 & 0.03 & -0.04 & 0.03 \\
\hline \multicolumn{7}{|l|}{ Control } \\
\hline Gender & - & & -0.05 & $0.02 * *$ & -0.05 & $0.02 * *$ \\
\hline \multicolumn{7}{|l|}{ Fairness } \\
\hline $\begin{array}{l}\text { Confidence in } \\
\text { the police }\end{array}$ & - & & - & & 0.37 & $0.04 * *$ \\
\hline \multicolumn{7}{|l|}{ Random effects } \\
\hline Individual level $\left(\sigma^{2}\right)$ & 1.00 & $0.00 * *$ & 1.00 & $0.00 * *$ & 1.00 & $0.00 * *$ \\
\hline $\begin{array}{l}\text { Contextual level }\left(\sigma_{\mu 0}^{2}\right) \\
\text { Model properties }\end{array}$ & 0.74 & $0.14 * *$ & 0.65 & $0.12 * *$ & 0.63 & $0.12 * *$ \\
\hline $\begin{array}{l}\text { Number of } \\
\text { cases } \\
\text { (countries) }\end{array}$ & $67,617(58)$ & & $67,617(58)$ & & $67,617(58)$ & \\
\hline $\begin{array}{l}\text { Wald test } \\
\text { (joint } \chi^{2} \text { ); } \\
\text { (degrees of } \\
\text { freedom) }\end{array}$ & $105.8(1)$ & & $1,221.9(11)$ & & $1,326.8(12)$ & \\
\hline
\end{tabular}

Note: Dependent variable: generalized trust ("Generally speaking, would you say that most people can be trusted [1] or that you can't be too careful in dealing with people [0]?"). Coefficients are not standardized; all variables are rescaled so that the lowest value is 0 and the highest 1 . Coefficients indicate the change associated with moving from the lowest to the highest value. The individual-level variable is controlled for contextual variance. The Wald test is an approximate $\chi^{2}$ based test of the fit of the model.

${ }^{*} p<.10 . * * p<.05$. 
variables, we can establish the variance to be explained for the individual and societal levels. Next, we estimate the impact of the individual-level characteristics-controlling for but not yet modeling societal variables (Table 3, Models 2 and 3). We proceed to estimate the influence of institutional variables, certain control variables, and cross-level interaction effects (Table 4).

The first conclusion that we can make about Table 3 and the empty model is that a hierarchical model is appropriate for our analysis. It is clear that the total variance (both individual level and contextual) of generalized trust can to a large degree be explained by differences between countries: About $18 \%$ of the total variance can be accounted for, namely, 0.74 / (3.29 +0.74 ). The estimates in Models 2 and 3 also indicate that the development of generalized trust depends on the social integration of the individual and on his or her cognitive resources. Active members of an association are more likely to exhibit generalized trust than those not involved in such clubs. Contrary to the expectations of social capital theorists (Putnam, 2000; Zmerli, 2003), differences between bonding and bridging associational networks do not play a role: Members of both types of associations exhibit higher levels of generalized trust. A higher level of education also positively influences an individual's propensity to develop generalized trust.

In addition to individual resources and social integration, certain attitudes and values also influence the development of trust. Our results indicate that individuals who for example are highly satisfied with their lives and are relatively cosmopolitan are less hesitant to place their trust in others. We also find that men are more likely to exhibit generalized trust than women and that the probability of trusting increases with age. We do not find statistically significant results for marital/relationship status, moral codes, or religious affiliation. Nevertheless, including these individual-level variables notably improves the fit of the model (even if the contextual variance of these factors is very high). ${ }^{13}$

In examining the influence of contextual factors, we first ascertain the influence institutional factors such as fairness, incorruptibility, nonpartisanship, and justice have on individuals. Our first estimation shows the influence of individual-level trust in the police on generalized trust (Model 3). This demonstrates that individuals who place a great deal of trust in the law enforcement are less hesitant to place trust in others. The greater the trust in the police, the more likely it is that people will trust others in society. At this stage however, it remains unclear whether trust in institutions leads to generalized trust or if the relationship works in the opposite direction - that is, only trusting people are also willing to trust such institutions (Uslaner, 2002). 
Table 4

Two-Level Models Explaining Generalized Trust

\begin{tabular}{|c|c|c|c|c|c|c|}
\hline & $\begin{array}{c}\text { Model } \\
4\end{array}$ & $S E$ & $\begin{array}{c}\text { Model } \\
5\end{array}$ & $S E$ & $\begin{array}{c}\text { Model } \\
6\end{array}$ & $S E$ \\
\hline \multicolumn{7}{|l|}{ Fixed effects } \\
\hline $\begin{array}{l}\text { Constant } \\
\text { Individual level } \\
\text { Social networks }\end{array}$ & -3.41 & $0.40 * *$ & -3.65 & $1.05 * *$ & -4.49 & $1.03 * *$ \\
\hline $\begin{array}{l}\text { Activity in } \\
\text { bridging } \\
\text { associations }\end{array}$ & 0.18 & $0.02 * *$ & 0.18 & $0.02 * *$ & 0.05 & 0.11 \\
\hline $\begin{array}{l}\text { Activity in } \\
\text { bonding } \\
\text { associations }\end{array}$ & 0.16 & $0.03 * *$ & 0.17 & $0.03 * *$ & 0.20 & $0.03 * *$ \\
\hline $\begin{array}{l}\text { Marital status } \\
\text { Resources }\end{array}$ & 0.00 & 0.02 & 0.00 & 0.02 & -0.01 & 0.02 \\
\hline Education & 0.69 & $0.03 * *$ & 0.70 & $0.03^{* *}$ & 0.71 & $0.03 * *$ \\
\hline \multicolumn{7}{|l|}{ Attitudes and habits } \\
\hline Life satisfaction & 0.73 & $0.05^{* *}$ & 0.73 & $0.05^{* *}$ & 1.07 & $0.14 * *$ \\
\hline Moral codes & 0.01 & 0.06 & 0.01 & 0.06 & 0.03 & 0.06 \\
\hline $\begin{array}{c}\text { Cosmopolitan } \\
\text { orientation }\end{array}$ & 0.14 & $0.04 * *$ & 0.14 & $0.04 * *$ & 0.12 & $0.04 * *$ \\
\hline $\begin{array}{l}\text { Religious } \\
\text { denomination }\end{array}$ & -0.04 & 0.03 & -0.04 & 0.03 & -0.05 & 0.03 \\
\hline \multicolumn{7}{|l|}{ Control } \\
\hline Gender & -0.05 & $0.02 * *$ & -0.05 & $0.02 * *$ & -0.06 & $0.02 * *$ \\
\hline Age & 0.25 & $0.05^{* *}$ & 0.25 & $0.05^{* *}$ & 0.28 & $0.05^{* *}$ \\
\hline \multicolumn{7}{|l|}{ Fairness } \\
\hline $\begin{array}{l}\text { Confidence in } \\
\text { the police }\end{array}$ & 0.37 & $0.04 * *$ & 0.38 & $0.04 * *$ & 0.37 & $0.04 * *$ \\
\hline \multicolumn{7}{|l|}{ Contextual level } \\
\hline \multicolumn{7}{|l|}{ Fairness } \\
\hline Rule of law & 0.60 & 0.40 & 0.04 & 0.43 & 0.11 & 0.42 \\
\hline $\begin{array}{l}\text { Independent } \\
\text { judiciary }\end{array}$ & 0.02 & 0.22 & -0.02 & 0.23 & 0.02 & 0.22 \\
\hline $\begin{array}{l}\text { Degree of } \\
\text { corruption }\end{array}$ & 1.22 & $0.50 * *$ & 1.10 & $0.50^{* *}$ & 0.99 & $0.48 * *$ \\
\hline \multicolumn{7}{|l|}{ Universality } \\
\hline $\begin{array}{l}\text { Inequality } \\
\quad \text { (Gini Index) }\end{array}$ & -0.71 & $0.36 * *$ & -0.62 & $0.36^{*}$ & 0.04 & 0.41 \\
\hline $\begin{array}{l}\text { Health expenditure } \\
\text { Power-sharing }\end{array}$ & 0.23 & 0.55 & -0.20 & 0.58 & -0.19 & 0.56 \\
\hline $\begin{array}{l}\text { Power-sharing regime } \\
\text { typology }\end{array}$ & -0.57 & 0.38 & -0.48 & 0.37 & -0.34 & 0.36 \\
\hline
\end{tabular}


Table 4 (continued)

\begin{tabular}{|c|c|c|c|c|c|c|}
\hline & $\begin{array}{c}\text { Model } \\
4\end{array}$ & $S E$ & $\begin{array}{l}\text { Model } \\
5\end{array}$ & $S E$ & $\begin{array}{l}\text { Model } \\
6\end{array}$ & $S E$ \\
\hline \multicolumn{7}{|l|}{ Sharing of } \\
\hline $\begin{array}{l}\text { Proportional } \\
\text { representation } \\
\text { (PR) system }\end{array}$ & 0.47 & $0.25^{*}$ & 0.45 & $0.27 *$ & 0.23 & 0.28 \\
\hline $\begin{array}{l}\text { Degree of } \\
\text { democracy }\end{array}$ & 0.44 & 0.30 & 0.40 & 0.29 & 0.36 & 0.28 \\
\hline \multicolumn{2}{|l|}{ Society composition } & & & & & \\
\hline Ethnic homogeneity & - & & 0.52 & 0.38 & 0.42 & 0.37 \\
\hline $\begin{array}{l}\text { Population size }(\log .) \\
\text { Resources }\end{array}$ & - & & 0.15 & 0.53 & -0.01 & 0.51 \\
\hline GDP per capita & - & & 1.40 & $0.54 * *$ & 1.16 & $0.52 * *$ \\
\hline $\begin{array}{l}\text { Literacy rate } \\
\text { Regional provenance }\end{array}$ & - & & 0.09 & 1.01 & 1.01 & 0.98 \\
\hline $\begin{array}{l}\text { Dummy Western } \\
\text { European country }\end{array}$ & - & & -0.23 & 0.27 & -0.08 & 0.26 \\
\hline \multicolumn{7}{|l|}{ Interactions } \\
\hline$P R \times$ Bridging & & & & & 0.19 & $0.12^{*}$ \\
\hline Slope variance & & & & & 0.08 & $0.02 * *$ \\
\hline Covariance & - & & - & & -0.12 & $0.04 * *$ \\
\hline $\begin{array}{l}\text { Gini } \times \text { Life } \\
\text { Satisfaction }\end{array}$ & & & & & -0.89 & $0.13 * *$ \\
\hline Slope variance & & & & & 0.24 & $0.07 * *$ \\
\hline $\begin{array}{l}\text { Covariance } \\
\text { Random effects }\end{array}$ & - & & - & & 0.20 & $0.08 * *$ \\
\hline Individual-level $\left(\sigma^{2}\right)$ & 1 & $0.00 * *$ & 1.00 & $0.00 * *$ & 1.00 & $0.00 * *$ \\
\hline $\begin{array}{l}\text { Contextual-level }\left(\sigma_{\mu 0}^{2}\right) \\
\text { Model properties }\end{array}$ & .35 & $0.07 * *$ & 0.32 & $0.06^{* *}$ & 0.54 & $0.12 * *$ \\
\hline $\begin{array}{l}\text { Number of cases } \\
\text { (countries) }\end{array}$ & $67,617(58)$ & & $67,617(58)$ & & $67,617(58)$ & \\
\hline $\begin{array}{l}\text { Wald test } \\
\left.\qquad \text { (joint } \chi^{2}\right) \\
\quad(\text { degrees of freedom) }\end{array}$ & $1,480.8(21)$ & & $1,522.4(26)$ & & $1,166.2(28)$ & \\
\hline
\end{tabular}

Note: See Table 3.

$* p<.10{ }^{* *} p<.05$.

One way to circumvent the causality and endogeneity problem is to include institutional variables at the level of social contexts. Using hierarchical modeling, we can establish whether two individuals with equal characteristics exhibit different probabilities of propensity to generalized 
trust under various institutional conditions. The next set of estimations aims to answer this very question. The first step is to include the nine political-institutional variables in Model 4 (see Table 4). Next, we introduce the control variables at the societal level (again, on the basis of Model 4). Finally, Model 6 estimates cross-level interaction effects.

A comparison with Table 3 shows that including the contextual variables does not change the signs or the statistical significance of the various individual characteristics. Three institutional variables are influential at statistically significant levels. First, the level of corruption in a country is shown to be a factor in determining the level of generalized trust in a given country. In countries where corruption is widespread, people are less likely to develop trust than people in countries with incorruptible institutions. Second, the likelihood that an individual develops trust increases in countries with more equitable income distributions-such as in a welfare state that pursues universalistic goals. Third, proportional representation promotes generalized trust. In other words, institutions that succeed in distributing power and protecting minorities, thereby ensuring that all relevant interests are represented in the decision-making process, contribute to the development of trust at the individual level. These results imply that an Individual A, with the lowest values for all individual-level variables (i.e., a young, unmarried woman who is not active in associations, has little education, is dissatisfied with her life, and has no moral codes, cosmopolitan attitudes, or religious denomination) but nevertheless lives in a country with a low degree of corruption, high equality in terms of income distribution, and a proportional representation system has a probability of $27 \%$ to develop generalized trust. Furthermore, these three institutional variables remain statistically significant with the inclusion of control variables at the societal level. Finally, the rule of law, independence of the judiciary, health care spending, institutional and executive power-sharing, and prominence of democratic-pluralistic rules do not exhibit any statistically significant influence on the development of trust.

Turning to the control variables, we see that societies with high per capita GDPs provide a fertile environment for the development of generalized trust. However, neither the ethnic composition, size of the country, literacy rate, nor belonging to Western Europe influences the probability of trust formation. By including all contextual variables, the context dependent variance is reduced by $57 \%$, as compared to the empty model. ${ }^{14}$

In addition to the direct effects of the institutional context, institutions also condition the relationships between individual-level characteristics and the development of trust. The final step in our analysis is therefore to include the additive estimates of cross-level interaction effects, wherein we 
concentrate on the three institutional factors shown to be statistically significant (see Model 6). ${ }^{15}$ In estimating cross-level interaction effects we establish whether the effects of the individual features depend on the values of the contextual institutions. In other words, we ask if the strength and direction of the effects of the individual characteristics vary from context to context or if these effects are independent of the societal environment. Our conjecture is that the three statistically significant institutional factors will condition the effects of trust in the police, satisfaction with one's quality of life, and the activity in bonding and bridging associations. ${ }^{16}$

Based on theoretical perspective, we expect the following effects: First, we expect to find diminishing marginal returns regarding the influence of trust in the police on generalized trust in the context of less corruptible relevant institutions. In other words, in countries where the authorities are relatively incorruptible, the influence of trust in the police on generalized trust should be lesser. Second, we anticipate an interaction effect between satisfaction with one's quality of life and income equality. A high degree of satisfaction with one's quality of life increases the probability of exhibiting generalized trust. However, it is only in countries where the welfare state institutions ensure a relatively equal income distribution that satisfaction with one's quality of life will lead to generalized trust. In countries with high income inequality, people who are satisfied with their quality of life will be less likely to transform their satisfaction into generalized trust for the aforementioned stated reasons. In other words, the higher the level of income inequality in a country (i.e., the higher the Gini Index value), the weaker the effect satisfaction with one's quality of life has on generalized trust. Finally, we have shown that at the individual level, membership in clubs and associations increased the probability of exhibiting generalized trust. At the contextual level, systems of proportional representation also have been shown to have a positive impact. Against this background, we hypothesize that the effect of associational membership will be stronger in countries with systems of proportional representation (and correspondingly, better chances for political participation).

The basis of our estimates is Model 5 from Table 4. The results for interaction effects are as follows (see Model 6): ${ }^{17}$ The expected conditioning effect of income inequality on the effect of satisfaction with one's quality of life can be empirically confirmed; the positive effect of satisfaction with one's quality of life drops in countries with greater income inequality. Satisfaction with one's quality of life is more likely to translate into generalized trust in countries with institutions that address income inequality. In countries where income is very unequally distributed, not only is the basic level of trust lower, but any increase in satisfaction with one's quality of life will also be less likely 
to lead to generalized trust. We also find empirical support for the conjecture that a system of proportional representation conditions the effect of associational membership on trust. In countries with proportional representation, active membership in bridging networks has a stronger effect on the likelihood of expressing generalized trust than in countries with more competition-oriented electoral systems. Contrary to our expectations, low levels of corruption do not reduce the impact of trust in the police on generalized trust. Furthermore, proportional representation does not affect the impact of active membership in bonding associations on generalized trust.

\section{Conclusions}

In recent years scholars in the social sciences have shown resurgent interest in the analysis of trust. Our contribution follows this path by investigating the sources of social trust. In addition to individual-level characteristics, we focus on the influence of the political institutions that provide the context for the development of trust. We argue that universalistic, power-sharing institutions, as well as those that sanction noncooperative behavior, provide an environment of credibility-allowing generalized trust to flourish. This finding itself supports the main insight of actor-centered institutionalism, according to which, "institutional rules provide a basis for expectations of reciprocity, and thereby allow for social interactions beyond the sphere of personal acquaintance" (Mayntz \& Scharpf, 1995, p. 47). Our findings speak for the applicability of this insight to the topic of social trust.

With regard to the most important contextual factors, we find that countries whose authorities are seen as incorruptible, whose institutions of the welfare state reduce income disparities, and whose political interests are proportionally represented have citizens who are more likely to place trust in one another. Beyond this, we find that institutional factors condition the effects of individual-level variables. Relatively high income equality intensifies the positive influence that satisfaction with one's quality of life has on generalized trust. Moreover, electoral systems that promote the sharing of power strengthen the positive influence membership in bridging associations has on generalized trust. What this study implies is a realistic, top-down approach to producing generalized trust through political institutions. Fair, nonpartisan, incorruptible, universalistic, and power-sharing/consensual institutions should, according to the results presented, at the very least not stand in the way of the development of generalized trust. 
In this article we extended the institutional theory of trust by introducing another facet of institutions. Whereas previous research highlights the dimensions of fairness and universalism, we have focused on the powersharing quality of institutions - a rather neglected institutional dimension hitherto. We have argued that institutions with a greater capacity for consensual and power-sharing are more likely to facilitate the development of social trust. In particular, the electoral system was shown to be a trustgenerating fundament in our analyses. In proportional systems, the fair representation of all societal interests can be guaranteed, as well as the protection of minorities from exploitation by the majority. This result can be considered to be an indication that consensus democracies can promote generalized trust because the proportional electoral system provides the foundation of the institutional logic of this form of democracy (Taagepera, 2003). Moreover, this kind of collective veto points configuration leads to more shared responsibility, extended negotiation, and logrolling, all of which should reduce the political and social distances between the interests involved. These norms of nonhierarchical decision making, which require collective agency in institutions, are inherent in consensus democracies and form the breeding ground for the development of trust. However, according to our analyses, competitive veto points, as found in a federal state architecture (as measured by Norris's [2005] index of power sharing), do not systematically influence the creation of trust. In general, constitutional features such as federalism create competitive veto points by allowing agents who control different bodies to prevent specific interests from being enacted. In this regard, competitive veto players like federalism represent separate agencies that compete against each other and thus strengthen conflicting interests. In this case, opposites tend to be maintained instead of bridged, thereby reducing the potential for the creation of trust.

Our findings should be viewed as the provisional results of an empirically oriented analysis of trust. As certain limits are imposed on this research design by the limited availability and reliability of micro- and macro-level data, the hierarchical model can be seen as a statistical method that complements previous investigations. To pinpoint the influence of political conditions on the development of trust in a systematic manner, more precise estimates and measures of political-institutional configurations are needed, particularly with regard to the key concepts of fairness, universality, and inclusiveness. This investigation however has taken the first step toward greater clarity in this research area. 


\section{Appendix \\ Hypotheses and Operationalizations}

The following table presents the applied variables, their operationalizations and sources, and the expected directions of the relationships (Exp).

\begin{tabular}{|c|c|c|}
\hline Variable & Operationalization and Source ${ }^{a}$ & $\operatorname{Exp}^{b}$ \\
\hline \multicolumn{3}{|l|}{$\begin{array}{l}\text { Individual-level } \\
\text { variables }\end{array}$} \\
\hline $\begin{array}{l}\text { Generalized } \\
\text { trust }\end{array}$ & $\begin{array}{l}\text { Generally speaking, would you say that most people can be trusted } \\
\text { (1) or that you can't be too careful in dealing with people }(0) \\
\text { [WVS a165]? }\end{array}$ & \\
\hline $\begin{array}{l}\text { Activity in } \\
\text { clubs/associa- } \\
\text { tions (bridg- } \\
\text { ing) }\end{array}$ & $\begin{array}{l}\text { The variable takes the value } 1 \text { if the respondent is an active member } \\
\text { of, or does unpaid work for, the following kinds of organization: } \\
\text { church organizations [WVS a082/a098], sports or recreation } \\
\text { [WVS a091/a099], cultural activities [WVS a083/a100], and/or } \\
\text { environment, conservation, animal rights [WVS a088/a103]. The } \\
\text { variable takes the value } 0 \text { if the respondent is only a passive } \\
\text { member, belongs to none of the aforementioned kinds of club/ } \\
\text { association, and does no such unpaid work. }\end{array}$ & + \\
\hline $\begin{array}{l}\text { Activity in } \\
\text { clubs/associa- } \\
\text { tions (bond- } \\
\text { ing) }\end{array}$ & $\begin{array}{l}\text { The variable takes the value } 1 \text { if the respondent is an active member } \\
\text { of, or does unpaid work for, the following kinds of organization: } \\
\text { work labor unions [WVS a084/a101], political parties [WVS } \\
\text { a085/a102], and/or work professional associations [WVS a089/ } \\
\text { a104]. The variable takes the value } 0 \text { if the respondent is only a } \\
\text { passive member, belongs to none of the aforementioned kinds of } \\
\text { club/association, and does no such unpaid work. }\end{array}$ & - \\
\hline $\begin{array}{l}\text { Married/ } \\
\text { cohabiting }\end{array}$ & $\begin{array}{l}\text { "Are you currently . . . married; living together as married; } \\
\text { divorced; separated; widowed; single" [WVS x007; recoded: } \\
\text { married or living together }=1 \text {; all other options }=0 \text { ]. }\end{array}$ & + \\
\hline Education & $\begin{array}{l}\text { Scale from no formal education (1) to university-level-education } \\
\text { with degree (8) [WVS x025] }\end{array}$ & + \\
\hline $\begin{array}{l}\text { Satisfaction } \\
\text { with one's } \\
\text { quality } \\
\text { of life }\end{array}$ & $\begin{array}{l}\text { Factor analysis (principal components analysis) is used to generate a } \\
\text { single significant factor from the following two items (eigenvalue } \\
=1.48 \text { ) that explains } 74.3 \% \text { of the variance (lowest loading: } 0.86 \text { ): } \\
\text { "Taking all things together, would you say you are: very happy (4), } \\
\text { quite happy (3), not very happy (2), not at all happy (1)?" [WVS } \\
\text { a008]. } \\
\text { "All things considered, how satisfied are you with your life as a whole } \\
\text { these days. } 1=\text { dissatisfied; } 10=\text { satisfied" [WVS al70]. } \\
\text { Factor values are made into a scale, ranging from }-2.80 \text { to } 1.53 \text {. }\end{array}$ & + \\
\hline Moral codes & $\begin{array}{l}\text { Factor analysis (principal components analysis) is used to generate } \\
\text { a single significant factor from the following three items } \\
\text { (eigenvalue }=1.75 \text { ), that explains } 58.4 \% \text { of the variance (lowest } \\
\text { loading: } 0.53 \text { ): }\end{array}$ & + \\
\hline
\end{tabular}




\section{Appendix (continued)}

\begin{tabular}{|c|c|c|}
\hline Variable & Operationalization and Source ${ }^{a}$ & $\operatorname{Exp}^{\mathrm{b}}$ \\
\hline & $\begin{array}{l}\text { "Please tell me for each of the following statements whether you } \\
\text { think it can always be justified (10), never be justified (1), or } \\
\text { something in between": }\end{array}$ & \\
\hline & $\begin{array}{l}\text { Claiming government benefits to which you are not entitled [WVS } \\
\text { f114] }\end{array}$ & \\
\hline & Cheating on taxes if you have a chance [WVS f116] & \\
\hline & Someone accepting a bribe in the course of their duties [WVS f117] & \\
\hline & Factor values are made into a scale, ranging from -0.69 to 5.11 . & \\
\hline \multirow[t]{4}{*}{$\begin{array}{l}\text { Cosmopolitan } \\
\text { attitudes }\end{array}$} & $\begin{array}{l}\text { Factor analysis (principal components analysis) is used to generate } \\
\text { a single significant factor from the following two items } \\
\text { (eigenvalue }=1.08 \text { ), that explains } 53.8 \% \text { of the variance (lowest } \\
\text { loading: } 0.54 \text { ): }\end{array}$ & + \\
\hline & $\begin{array}{l}\text { "How proud are you to be Swiss (substitute your own nationality } \\
\text { for "Swiss"); very proud (1), quite proud (2), not very proud (3), } \\
\text { not at all proud (4)" [WVS g006]. }\end{array}$ & \\
\hline & $\begin{array}{l}\text { "To which of these geographical groups would you say you belong } \\
\text { first of all?" [WVS g001 recoded: } 0 \text { if the first answer was } \\
\text { "town" or "region"; } 1 \text { if the first answer was "nation," } \\
\text { "continent," or "the world as a whole." }\end{array}$ & \\
\hline & Factor values are made into a scale, ranging from -1.23 to 2.78 & \\
\hline $\begin{array}{l}\text { Religious } \\
\text { denomination }\end{array}$ & $\begin{array}{l}\text { "Do you belong to a religious denomination?" [WVS f024] yes = } \\
1 ; \text { no }=0 \text {. }\end{array}$ & + \\
\hline Gender & Dummy variable with $0=$ male and $1=$ female [WVS x001, recoded]. & - \\
\hline Age & $\begin{array}{l}\text { "Can you tell me your year of birth, please-this means you are } \ldots \\
\text { years old" [WVS x003]. }\end{array}$ & + \\
\hline $\begin{array}{l}\text { Trust in the } \\
\text { police }\end{array}$ & $\begin{array}{l}\text { "I am going to name a number of organizations. For each one, could } \\
\text { you tell me how much confidence you have in them: is it a great } \\
\text { deal of confidence (4), quite a lot of confidence (3), not very much } \\
\text { confidence (2) or none at all (1)?"- - the police [WVS e074]. }\end{array}$ & + \\
\hline \multicolumn{3}{|l|}{$\begin{array}{l}\text { Country-level } \\
\text { variables }^{\mathrm{c}}\end{array}$} \\
\hline Rule of law & $\begin{array}{l}\text { Estimated strength of rule of law (interdependence of state powers, } \\
\text { legal sanctions on abuse of office, protections of civil liberties). } \\
\text { Takes values from } 0 \text { (no rule of law) to } 5 \text { (strong rule of law). } \\
\text { Source: Bertelsmann Foundation (2003); Bertelsmann } \\
\text { Transformation Index (all Western nontransitional countries } \\
\text { coded } 6 \text { in the absence of contradictory evidence). }\end{array}$ & + \\
\hline $\begin{array}{l}\text { Independent } \\
\text { judiciary }\end{array}$ & $\begin{array}{l}\text { Takes the value } 1 \text { if there is an independent judiciary. In all other } \\
\text { cases, takes the value } 0 \text {. Source: Henisz (2004). }\end{array}$ & + \\
\hline Corruption & $\begin{array}{l}\text { Index (1-6) of estimated corruption; high values indicate low risk } \\
\text { of corruption. Source: International Country Risk Guide (2004) } \\
\text { and Kaufmann, Kraay, and Zoido-Lobatón (1999). }\end{array}$ & + \\
\hline
\end{tabular}




\section{Appendix (continued)}

\begin{tabular}{|c|c|c|}
\hline Variable & Operationalization and Source ${ }^{a}$ & $\operatorname{Exp}^{b}$ \\
\hline $\begin{array}{l}\text { Degree of } \\
\text { income } \\
\text { equality }\end{array}$ & $\begin{array}{l}\text { The Gini Index expresses the distance of the actual income } \\
\text { distribution from a perfectly equal distribution. The higher the } \\
\text { index value, the further the actual distribution is from equality. } 0 \\
\text { indicates perfect equality; } 100 \text { perfect inequality. Source: CIA } \\
\text { World Factbook (2006); values from } 1990 \text { to } 2005 \text {. }\end{array}$ & - \\
\hline $\begin{array}{l}\text { Public health } \\
\text { expenditures }\end{array}$ & $\begin{array}{l}\text { Official statistics on health spending as a percentage of GDP. } \\
\text { Source: World Health Organization (2006). }\end{array}$ & + \\
\hline $\begin{array}{l}\text { Power-sharing } \\
\text { regime } \\
\text { typology }\end{array}$ & $\begin{array}{l}\text { Three types of regime: pure power-concentration regimes (1); } \\
\text { mixed regimes (2); pure power-sharing regimes (3); Source and } \\
\text { operationalization: following Norris }(2005) \text {. }\end{array}$ & + \\
\hline $\begin{array}{l}\text { Sharing of } \\
\text { executive } \\
\text { power }\end{array}$ & $\begin{array}{l}\text { Effective number of parties in government according to Laakso and } \\
\text { Taagepera ( } \mathrm{N}=1 \text { / sum of squared seats of all seats held by gov- } \\
\text { ernment parties); the greater the index score, the more parties } \\
\text { with influence are in government. Source: DPI (Keefer, 2002), } \\
\text { own calculations. }\end{array}$ & + \\
\hline $\begin{array}{l}\text { System of } \\
\text { proportional } \\
\text { representation }\end{array}$ & $\begin{array}{l}\text { Takes the value } 1 \text { if the relevant sources refer to the country as hav- } \\
\text { ing a system of proportional representation. In all other cases, } \\
\text { takes the value } 0 \text {. Source (and detailed description of estimation): } \\
\text { Keefer (2002). }\end{array}$ & + \\
\hline $\begin{array}{l}\text { Degree of } \\
\text { democracy }\end{array}$ & $\begin{array}{l}\text { Standardized index (1-7) to measure political rights. Low values } \\
\text { represent weak political rights. Source: Freedom House, 2003; if } \\
\text { Survey } 2000 \text { or later: an average for the years } 1990,1995 \text {, and } \\
\text { 2000. If the WVS was taken before } 2000 \text {, only the years } 1990 \\
\text { and } 1995 \text { were averaged. }\end{array}$ & + \\
\hline \multicolumn{3}{|l|}{ Control variables } \\
\hline $\begin{array}{l}\text { Ethnic } \\
\text { homogeneity }\end{array}$ & $\begin{array}{l}\text { Rae-Index (Rae, } 1971) \text { for the various ethnic groups in a country } \\
(1-(1-\text { the sum of squares of the proportion) }) ; 1=\text { absolutely } \\
\text { homogeneous; } 0=\text { absolutely heterogeneous. Source: ClA World } \\
\text { Factbook (2006); own calculations. }\end{array}$ & + \\
\hline $\begin{array}{l}\text { Population } \\
\text { size }\end{array}$ & $\begin{array}{l}\text { Logged number of people in a country. Human Development Report } \\
\text { (2004). }\end{array}$ & - \\
\hline GDP per capita & GDP per capita in US\$. Source: UN Statistics Division (2005). & + \\
\hline Literacy rate & $\begin{array}{l}\text { Literacy rate (proportion of the population older than } 15 \text { years of } \\
\text { age who have good reading and writing skills). Average from } \\
\text { 1990-1991 and 2000-2001. Source: Human Development Report } \\
\text { (2004); CIA World Factbook (2006). }\end{array}$ & + \\
\hline Western Europe & Western-European countries $=1$; all other countries $=0$. & + \\
\hline
\end{tabular}

a. All data on the individual level come from the World Values Surveys (WVS) 1995-1997 and 1999-2001 (Inglehart, Basanez, Diez-Medrano, Halman, \& Luijkx, 2004). All calculations are weighted by the variable [weight WVS s017], following Inglehart et al. (2004).

b. Exp. $=$ theoretically derived expected direction of relationship $(+=$ positive relationship; $-=$ negative relationship).

c. If not indicated otherwise, for all macro variables, we used the values from the year prior to the WVS survey - if available; otherwise, we took the closest year available. 


\section{Notes}

1. With regard to the concept of trust, there exist several forms of this kind of expectation (Stolle, 2002). If not otherwise stated, trust is used synonymously with generalized or social trust, implying trust in strangers or those not personally known.

2. Initial ideas in this direction can already be found in You's work (2005). However, he does not name any concrete institutions and primarily focuses on the difference between democracies and autocracies. As there are clear differences within the group of democracies with regard to their levels of trust, a more extensive differentiation is necessary for this reason alone (see Table 1).

3. To increase the ability to generalize our findings, we also use data for countries that were only included in the wave of 1995-1997. These countries are Australia, Azerbaijan, Brazil, Colombia, the Dominican Republic, Georgia, New Zealand, Norway, Switzerland, and Uruguay.

4. Whereas the former rational choice-based argument implies that institutions impose sanctions on untrustworthy behavior, which makes people behave in a trustworthy manner, the more historical institutional perspective argues that institutions shape affective norms and habits through socialization mechanisms. From this perspective, universalistic, power-sharing, noncorrupt, nonpartisan institutions make people inherently trustworthy and influence the way people trust one another. Because the data do not differentiate between the rational choice and historical institutionalism arguments, both arguments are worth considering while we await studies pitting the two against each other. We are grateful to the reviewer for these points.

5. Some argue that well-functioning institutions are a substitute for trust-that is, institutions make trust redundant. According to Offe (1999), this view is flawed in at least two respects. First, both contracts and market competition are known to be incomplete; the same also applies to laws and constitutional regimes, which are not sacrosanct or eternal. Second, institutions are not conventions but rather quite the opposite - namely, patterns of precarious and potentially contested cooperations. In this view, the potential for being challenged in the name of alternative institutions is an essential feature of all institutions.

6. "Co-operation among un-equals is problematic because there will always be incentives for the poor, who will naturally be dissatisfied with the existing distribution of assets, to defect from co-operative arrangements" (Boix \& Posner, 1998, p. 688).

7. When decisions are seen to be made in a nonpartisan and fair manner, people are more likely to accept a negative outcome (Frohlich \& Oppenheimer, 1992). One can draw a parallel to a soccer match: Players are more likely to accept defeat when the referee performs his or her job fairly and without preference for either side. Conversely, the final score of a match in which the officials show a systematic preference for one team over the other is more likely to evoke protest.

8. Following Inglehart, Basanez, Diez-Medrano, Halman, and Luijkx (2004, p. 411), we conduct all calculations at the individual level using weightings.

9. For a more thorough discussion of the method we refer to the relevant literature on MLA (Goldstein, 1991, 1995; Hox, 1995; Jones, 1997). All models were calculated with MLwiN (Rasbash et al., 2002) using Restrictive Iterative Generalized Least Squares (RIGLS) and second order PQL (see Goldstein, 1995).

10. The following estimates are based on trust in the police at the individual level. Due to severe data limitations that would have negative implications for the generalizability of our findings, we refrain from including individual-level data on trust in the legal system. We do however include a measure of judicial independence at the macro level. 
11. We concede that the degree of income inequality (measured using the Gini Index) and state spending on health care are not institutional variables per se. However, given the absence of more direct measures of the role of the welfare state in our data and the importance attributed to these factors in the literature, we have chosen to view both inequality and health care spending as the outcomes of particular institutional structures-that is, as characteristic of welfare states (see Esping-Andersen, 1990). In addition, there is a broad consensus in the literature that both government polity and policies have a large impact on economic equality. Differences in social inequality have been linked to features of welfare states (Rothstein \& Uslaner, 2005).

12. Because these (control) variables are not our primary analytic interest, we refrain from going into a deeper theoretical discussion of their importance; we instead refer the reader to the relevant literature. The projected directions of causation reflect the findings on these variables in the literature.

13. Purely individual-level analyses imply that the total variance can be explained exclusively by individual-level characteristics. This is clearly not the case in our analysis.

14. In the null model, the contextual variance is 0.74 . The reduction to 0.32 in the two-level model implies an improvement of about $57 \%$.

15. Whereas in the previous estimates we analyzed differences between intercepts, we now consider differences in slopes.

16. In addition to theoretical justifications, this conjecture is supported by the empirical preconditions for a precise hierarchical analysis of these variables. The effect of trust in the police, satisfaction with one's life, and associational activity vary significantly from country to country. Modeling the individual variances of these effects on the basis of Model 6 gives the following slopes/covariances (standard errors in parentheses): trust in the police 0.10 $(0.03) / 0.00(0.03)$; satisfaction with life $0.32(0.09) /-0.24(0.08)$; membership of bridging clubs $0.09(0.02) /-0.11(0.03)$; membership of bonding clubs $0.08(0.03) /-0.07(0.03)$.

17. In our calculations we add the four interaction terms between the institutional factors that we find to have significant effects on the impacts of individual-level characteristics. In these estimates, not reported here, the interaction terms between corruption and trust in the police and between proportional representation and club membership are statistically insignificant. For this reason, Model 6 includes only the coefficients for the interaction terms that we find to be statistically significant.

\section{References}

Alesina, A., \& La Ferrara, E. (2000). Participation in heterogeneous communities. Quarterly Journal of Economics, 115, 847-904.

Anderson, C. J., \& Guillory, C. A. (1997). Political institutions and satisfaction with democracy: A cross-national analysis of consensus and majoritarian systems. American Political Science Review, 91, 66-81.

Anderson, C. J., \& Singer, M. M. (2008). The sensitive left and the impervious right. Multilevel models and the politics of inequality, ideology, and legitimacy in Europe. Comparative Political Studies, 41, 564-599.

Bertelsmann Foundation. (2003). Bertelsmann Transformation Index. Auf dem Weg zur marktwirtschaftlichen Demokratie. Gütersloh, Germany: Bertelsmann Stiftung.

Boix, C., \& Posner, D. N. (1998). Social capital: Explaining its origins and effects on government performance. British Journal of Political Science, 28, 686-693. 
CIA World Factbook. (2006). Retrieved January 29, 2009, from https://www.cia.gov/cia/ publications/factbook/ index.html

Coleman, J. (1990). Foundations of social theory. Cambridge, MA: Belknap.

Crepaz, M. M. L. (2008). Trust beyond borders. Immigration, the welfare state, and the identity in modern societies. Ann Arbor: University of Michigan Press.

Delhey, J., \& Newton, K. (2005). Predicting cross-national levels of social trust. Global pattern or Nordic exceptionalism. European Sociological Review, 21, 311-327.

Eisenstadt, S. N. (1995). Power, trust, and meaning: Essays in sociological theory. Chicago: University of Chicago Press.

Esping-Andersen, G. (1990). The three worlds of welfare capitalism. Princeton, NJ: Princeton University Press.

Freedom House. (2003). Freedom in the world. Country ratings 1972 through 2003. Retrieved February 10, 2009, from http://www.freedomhouse.org/ratings/index.htm

Freitag, M. (2003a). Beyond Tocqueville: The origins of social capital in Switzerland. European Sociological Review, 19, 217-232.

Freitag, M. (2003b). Social capital in (dis)similar democracies. The development of generalized trust in Japan and Switzerland. Comparative Political Studies, 36, 936-966.

Freitag, M. (2006). Bowling the state back in. Political institutions and the creation of social capital. European Journal of Political Research, 45, 123-152.

Frohlich, N., \& Oppenheimer, J. A. (1992). Choosing justice. An experimental approach to ethical theory. Berkeley: University of California Press.

Fukuyama, F. (1995). Trust: The social virtues and the creation of prosperity. New York: Free Press.

Gabriel, O. W., Kunz, V., Rossdeutscher, S., \& Deth, J. W. v. (2002). Sozialkapital und Demokratie. Zivilgesellschaftliche Ressourcen im Vergleich [Social capital and democracy: The resources of civil society in a comparative perspective]. Wien, Austria: WUV Universitätsverlag.

Goldstein, H. (1991). Nonlinear multilevel models, with an application to discrete response data. Biometrika, 78, 45-51.

Goldstein, H. (1995). Multilevel statistical models. New York: Hodder Arnold.

Hall, P. A., \& Taylor, R. C. A. (1996). Political science and the three new institutionalisms. Political Studies, 44, 936-957.

Hardin, R. (1992). The street-level epistemology of trust. Analyse und Kritik, 14, 152-176.

Henisz, W. J. (2004). The Political Constraint Index (POLCON) data set. Philadelphia: Wharton School of the University of Pennsylvania.

Herreros, F. (2004). The problem of forming social capital: Why trust? New York: Palgrave Macmillan.

Herreros, F., \& Criado, H. (2008). The state and the development of social trust. International Political Science Review, 29, 53-71.

Hox, J. J. (1995). Applied multilevel analysis. Den Haag, the Netherlands: TT-Publikaties.

Human development report. (2004). Retrieved February 10, 2009, from http://hdr.undp.org/ en/reports/global/hdr2004/

Inglehart, R., Basanez, M., Diez-Medrano, J., Halman, L., \& Luijkx, R. (2004). Human beliefs and values. A cross-cultural sourcebook based on the 1999-2002 values surveys. Bilbao, Spain: Fundación BBVA.

Inglehart, R., et al. (2000). World Values Surveys and European Values Surveys, 1981-1984, 1990-1993, and 1995-1997 [Computer file; ICPSR version]. Ann Arbor, MI: Institute for Social Research. 
International Country Risk Guide. (2004). International country risk guide. A business guide to political risk for international decisions. PRS Group.

Jones, K. (1997). Multilevel approaches to modeling contextuality. From nuisance to substance in the analysis of voting behaviour. In G. P. Westert \& R. N. Verhoeff (Eds.), Places and people. Multilevel modeling in geographical research (pp. 19-43). Utrecht, the Netherlands: Netherlands Geographical Studies.

Kääriäinen, J., \& Lehtonen, H. (2006). The variety of social capital in welfare state regimes. A comparative study of 21 countries. European Societies, 8, 27-57.

Kaufmann, D., Kraay, A., \& Zoido-Lobatón, P. (1999). Governance matters. Six new aggregate measures capturing various dimensions of governance provide new evidence of a strong causal relationship from better governance to better development outcomes (Policy Research Working Paper 2196). New York: World Bank Development Research Group Macroeconomics and Growth and World Bank Institute Governance, Regulation, and Finance.

Keefer, P. (2002). DPI2000 database of political institutions. New York: Changes and Variable Definitions Development Research Group, World Bank.

Kumlin, S., \& Rothstein, B. (2005). Making and breaking social capital. The impact of welfare state institution. Comparative Political Studies, 38, 339-365.

Levi, M. (1998). A state of trust. In V. Braithwaite \& M. Levi (Eds.), Trust and governance (pp. 77-101). New York: Russell Sage.

Lijphart, A. (1999). Patterns of democracy. Government forms and performance in thirty-six democracies. New Haven, CT: Yale University Press.

Mayntz, R., \& Scharpf, F. (1995). Der Ansatz des akteurzentrierten Institutionalismus [The approach of actor centered institutionalism]. In R. Mayntz \& F. Scharpf (Eds.), Gesellschaftliche Selbstregelung und politische Steuerung (pp. 39-72). Frankfurt, Germany: Campus.

Nannestad, P. (2008). What have we learned about generalized trust, if anything. Annual Review of Political Science, 11, 413-436.

Neller, K. (2008). What makes people trust in their fellow citizens. In H. Meulemann (Ed.), Social capital in Europe: Similarity of countries and diversity of people. Multi-level analyses of the European Social Survey 2002 (pp. 103-133). Boston: Brill Academic Publishers.

Newton, K. (2001). Trust, social capital, civil society, and democracy. International Political Science Review, 22, 201-214.

Newton, K., \& Norris, P. (2000). Confidence in public institutions: Faith, culture, or performance? In S. J. Pharr \& R. D. Putnam (Eds.), Disaffected democracies. What's troubling the trilateral countries? (pp. 52-73). Princeton, NJ: Princeton University Press.

Nooteboom, B. (2007). Social capital, institutions and trust. Review of Social Economy, 65, 29-53.

Norris, P. (2005, April). Do power-sharing institutions work? Stable democracy and good governance in divided societies. Paper presented at the Midwest Political Science Association Annual Convention, Chicago.

Offe, C. (1999). How can we trust our fellow citizens? In M. E. Warren (Ed.), Democracy and trust (pp. 42-87). Cambridge, UK: Cambridge University Press.

Oorschot, W. v., \& Arts, W. (2005). The social capital of European welfare states. The crowding out hypothesis revisited. Journal of European Social Policy, 15, 5-26.

Paxton, P. (2007). Association memberships and generalized trust: A multilevel model across 31 countries. Social Forces, 86, 47-76. 
Putnam, R. D. (1993). Making democracy work. Civic traditions in modern Italy. Princeton, NJ: Princeton University Press.

Putnam, R. D. (2000). Bowling alone. The collapse and revival of American community. New York: Simon \& Schuster.

Putnam, R. D. (2007). E pluribus unum. Diversity and community in the twenty-first century. The 2006 Johan Skytte Prize Lecture. Scandinavian Political Studies, 30, 137-174.

Rae, D. W. (1971). The political consequences of electoral laws. New Haven, CT: Yale University Press.

Rasbash, J., Browne, W., Goldstein, H., Yang, M., Plewis, I., Healy, M., et al. (2002). A user's guide to MlwiN. Version $2 d$ for use with MlwiN 1.10. London: Centre for Multilevel Modelling, Institute of Education, University of London.

Rothstein, B. (2005). Social traps and the problem of social trust. Cambridge, UK: Cambridge University Press.

Rothstein, B., \& Stolle, D. (2003). Social capital, impartiality and the welfare state: An institutional approach. In M. Hooghe \& D. Stolle (Eds.), Generating social capital (pp. 191-209). New York: Palgrave.

Rothstein, B., \& Uslaner, E. M. (2005). All for all. Equality, corruption and social trust. World Politics, 58, 41-72.

Stadelmann-Steffen, I., \& Freitag, M. (2007). Der ökonomische Wert sozialer Beziehungen. Eine empirische Analyse zum Verhältnis von Vertrauen, sozialen Netzwerken und wirtschaftlichem Wachstum im interkulturellen Vergleich [The economic value of social relations: An empirical analysis of the relationship between trust, social networks and economic growth in a comparative perspective]. Kölner Zeitschrift fïr Soziologie und Sozialpsychologie (Sonderheft $\mathrm{Nr}$. 47), 294-320.

Steenbergen, M. R., \& Jones, B. S. (2002). Modeling multilevel data structures. American Journal of Political Science, 46, 218-237.

Stolle, D. (2002). Trusting strangers. The concept of generalized trust in perspective. Österreichische Zeitschrift für Politikwissenschaft, 31, 397-412.

Stolle, D., Soroka, S., \& Johnston, R. (2008). When does diversity erode trust? Neighborhood diversity, interpersonal trust and the mediating effect of social interactions. Political Studies, 56, 57-75.

Sztompka, P. (1995). Vertrauen. Die fehlende Ressource in der postkommunistischen Gesellschaft [Trust: The missing link in the post-communist society]. In B. Niedelmann (Ed.), Politische Institutionen im Wandel (pp. 254-276). New York: Springer.

Taagepera, R. (2003). Arend Lijphart's dimensions of democracy: Logical connections and institutional design. Political Studies, 51, 1-19.

UN Statistics Division. (2005). UN statistic report. Retrieved February 10, 2009, from http:// unstats.un.org/unsd/snaama/Introduction.asp

Uslaner, E. M. (2002). The moral foundations of trust. Cambridge, UK: Cambridge University Press.

Whiteley, P. (2000). Economic growth and social capital. Political Studies, 48, 443-466.

World Health Organization. (2006). World health report. Retrieved from http:// www.who.int/ whr/2006/annex/06_annex2_en.pdf

You, J.-S. (2005). Corruption and inequality as correlates of social trust: Fairness matters more than similarity. Unpublished manuscript, Harvard University, John F. Kennedy School of Government.

Zmerli, S. (2003). Applying the concepts of bonding and bridging social capital to empirical research. European Political Science, 2, 68-75. 
Markus Freitag is professor of comparative politics at the Department of Politics and Management, University of Konstanz, Germany. He has published on trust, social capital, direct democracy, comparative public policy, and voter participation.

Marc Bühlmann is a postdoc research associate with the NCCR Democracy at the Centre for Democracy in Aarau and at the University of Zurich where he leads several research projects on the measurement of the quality of democracy. He specializes in methods, social capital, democratic theory, and political sociology. 